\title{
Anestésicos
}

\section{ANESTÉSICOS GERAIS}

Grupos: anestésicos gerais de inalação (anestésicos voláteis) e anestésicos gerais intravenosos. Os primeiros são ainda subdivididos em: gases e liquidos voláteis (vapores). Os anestésicos gerais intravenosos são sólidos, administrando-se sob a forma de sais em solução. $\mathrm{Na}$ Tabela 1 estão indicados os anestésicos gerais mais importantes.

A anestesia geral está relacionada com uma alteração na transmissão dos impulsos nos neurónios do SNC. O mecanismo para esta mudança não é completamente conhecido. Pode resultar do bloqueio dos canais de ið̋es da membrana nervosa (muitos anestésicos reduzem o fluxo transmembranar). Pode estar relacionado com uma modificação não específica dos lípidos da membrana, pois a potência dos anestésicos gerais gasosos está estreitamente ligada à sua solubilidade nos lípidos das membranas. Por último, pode estar ligado a um efeito nos mecanismos neurotransmissores centrais. A sua acção pode ser descrita em estádios: estádio I - analgesia; estádio II - excitação; estádio III - anestesia cirúrgica; estádio IV - depressão medular. Este comportamento deriva da diferente sensibilidade das várias zonas do SNC ao agente anestésico e, tradicionalmente, é uma medida da profundidade da depressão. No entanto, com o uso dos anestésicos modernos estes estádios não são claramente observados devido à velocidade do seu efeito e aos seus efeitos irritantes mínimos.

\section{Anestésicos de inalação}

O efeito dos anestésicos de inalação depende da sua concentração no cérebro, a qual é determinada por factores farmacocinéticos (a farmacocinética estuda a obsorção, a distribuição, a biotransformação e a excreção dos fármacos no organismo) e da sua eficácia, uma característica farmacodinâmica (a farmacodinâmica estuda as acções farmacologicas e seus mecanismos dos fármacos no organismo).

Os factores farmacocinéticos de que depende a concentração no tecido cerebral e a velocidade com que é alcançada são vários: pressão parcial do gás, coeficiente de partição sangue-ar, etc.

Atendendo à natureza destes anestésicos no organismo (gases) avalia-se a concentração do fármaco pela sua pressão parcial. Quanto mais alta a pressão parcial do agente nos pulmð̄es (correspondente a uma pressão parcial inspirada elevada) maior o gradiente de transferência do anestésico dos alvéolos para o sangue. No sangue a pressão parcial do anestésico é função da sua solubilidade. $O$ coeficiente de partição sangue:ar indica a solubilidade do anestésico no sangue em comparação com a sua solubilidade no ar. Um agente com um baixo coeficiente de partição (baixa solubilidade no sangue, isto é, elevada pressão parcial) terá uma grande tendência a transferir-se do sangue para os tecidos (nomeadamente o cérebro). A absorção depende ainda da relação entre a pressão parcial do anestésico nos alvéolos (sangue arterial) e a do sangue venoso pulmonar. Este gradiente é função da captação do gás por todos os tecidos e quanto maior for, maior será a absorção. A velocidade com que as concentraçōes alvéolo-pulmonar e sanguínea são atingidas dependem da ventilação pulmonar e do fluxo sanguíneo pulmonar (débito cardíaco). Quanto maior a ventilação e menor o fluxo sanguíneo maior é a velocidade com que a pressão parcial se eleva e se estabelece a anestesia.

A eliminação inicia-se quando a mistura inspirada deixa de conter $o$ anestésico e os factores que entram em jogo são os mesmos que determinam a chegada do composto ao cérebro. A eliminação dos anestésicos de inalação faz-se quase totalmente pelos pulmőes, só poucos (halotano, por ex.) são metabolizados significativamente.

A eficácia destes fármacos é medida pela concentração mínima alveolar do anestésico que é definida como a concentração alveolar requerida para eliminar uma dor padronizada, em $50 \%$ de doentes. Cada anestésico tem o seu valor embora dependa um pouco da idade, estado cardiovascular do doente e outros factores.

Há certos efeitos tóxicos que são comuns a todos os anestésicos, como a depressão respiratória, a depressão cardiocirculatória, as náuseas e os vómitos. Outros efeitos são próprios de cada agente, embora na maioria não exista evidência científica inequívoca da sua toxicidade nos humanos, como é o caso do halotano ao qual tem sido atribuída uma pequena incidência de hepatite pós-operatória.

\section{Anestésicos intravenosos}

Os anestésicos intravenosos produzem perda rápida de consciência mas, geralmente, analgesia e relaxamento muscular insuficientes.

A farmacocinética destes anestésicos difere da dos inalados e, portanto, não é possível regular a intensidade do efeito por simples variação da concentração inalada. A sua potência depende do seu grau de ionização

\footnotetext{
- Faculdade de Farmácia de Lisboa
} 
TABELA 1

Anestésicos gerais de uso mais frequente

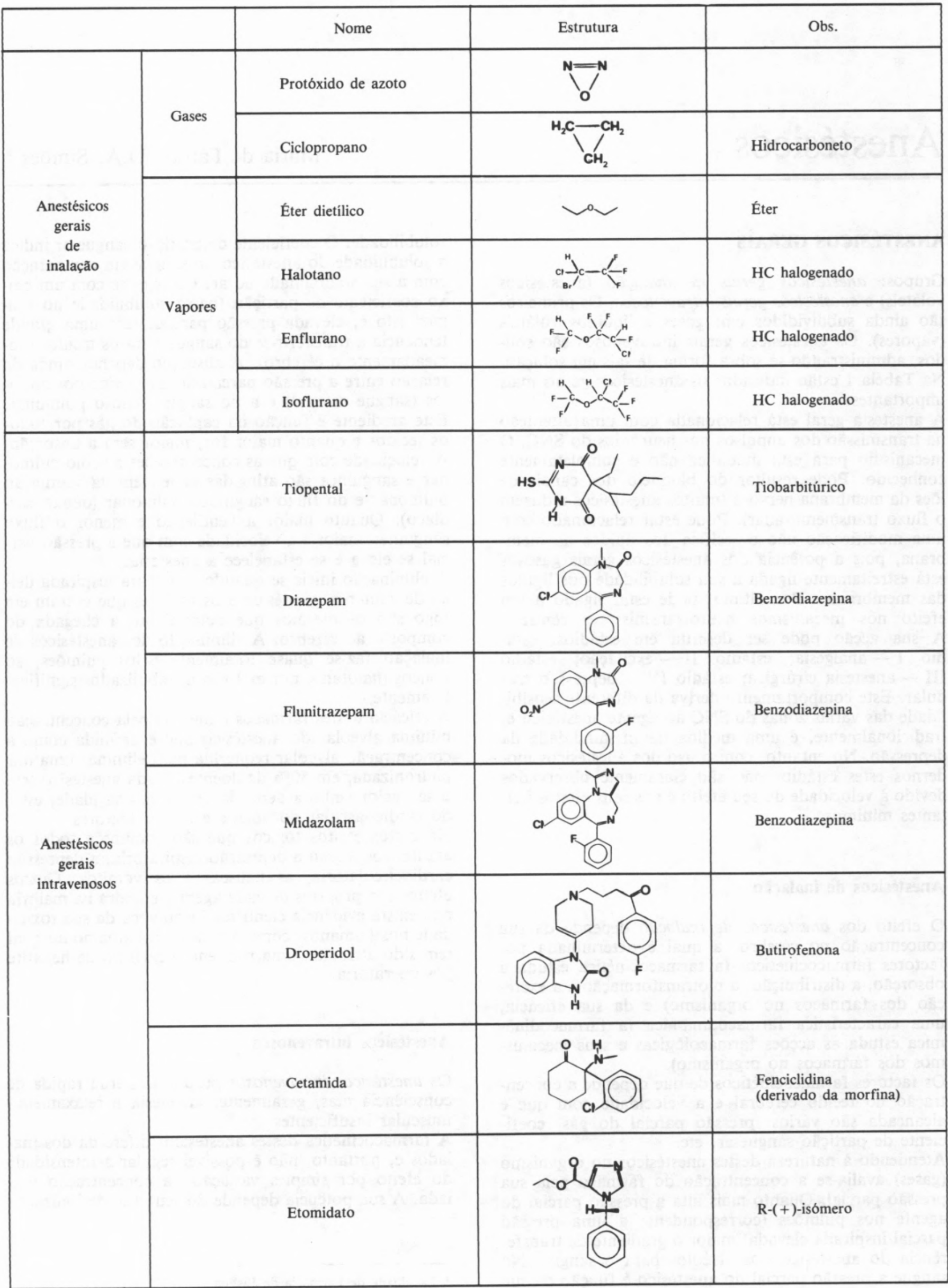


ao $\mathrm{pH}$ do líquido extracelular $(\mathrm{pH}=7.4)$, pois só a fracção não ionizada atravessa a barreira lipídica existente entre o sangue e o cérebro. A velocidade de penetração depende do coeficinete de partilha água:gordura da fracção não ionizada, sendo tanto maior, quanto menor for o coeficiente. A rápida penetração no cérebro destes fármacos, altamente lipossolúveis, é seguida de uma rápida redistribuição para outros orgãos e tecidos determinando a diminuição da sua concentração sanguínea e a velocidade do seu efeito.

A metabolização dos tiobarbitúricos que envolve, principalmente oxidação da cadeia lateral e a das benzodiazepinas, em que numa fase final há conjugação com o ácido glucurónico, faz-se no fígado. O etomidato é hidrolisado pelas esterases hepáticas e plasmáticas.

No que respeita à farmacodinamia, há que ter em conta os vários grupos de compostos. O tiopental tem uma grande solubilidade nos lípidos o que provoca uma transferência rápida para o cérebro permitindo uma anestesia ultra-rápida (um minuto). O mecanismo de acção é o dos barbitúricos em geral sendo usado normalmente como agente indutor da anestesia. As benzodiazepinas são tranquilizantes, e usam-se na indução da anestesia geral e como agentes anestésicos únicos (suplementados por um analgésico). Possuem actividade hipnótica, anticonvulsiva, sedativa e amnésica. A velocidade da indução é lenta e a duração da acção é curta para o midazolam, média para o diazepam e longa para o flumitrazepam. A cetamida produz inconsciência, amnésia e analgesia, não deprimindo o centro respiratório. Pode ser administrda não só intravenosamente, como os outros, mas também intramuscularmente. $\mathrm{O}$ droperidol é um neuroléptico, que se usa associado a um analgésico opiáceo, originando incapacidade de reacção (aquietação, neutralidade emocional, etc.), e adequa-se, geralmente, a intervençס̃es cirúrgicas pouco dolorosas ou de curta duração. O etomidato é um hipnótico de acção rápida e de recobro igualmente rápido mas não provoca analgesia.

Os efeitos tóxicos são diversos. Assim, os tiobarbitúricos podem ocasionar depressão respiratória e circulatória severa na anestesia profunda e laringospasmo na anestesia ligeira. As benzodiazepinas em doses elevadas levam a intoxicaçø̃es agudas como sintomas de embriageuz, vómitos, coma, depressão respiratória e colapso circulatório. A injecção intravenosa de diazepam é irritante local e por vezes pode provocar tromboflebites. A cetamida dá origem, entre outros efeitos, a sonhos, pesadelos, agitação psicomotora, taquicardia e hipotensão. O droperidol pode dar origem a alucinaçōes, ansiedade, hipotensão, salivação e a outras acçð̃es. $\mathrm{O}$ etomidato pode provocar depressão respiratória pouco marcada, náuseas, vómitos, irritação local (na injecção intravenosa) e outros efeitos ainda em estudo.

Outros factores a considerar na anestesia geral são: a medicação pré-anestésica, a indução, a manutenção e o recobro da anestesia. Com a medicação pré-anestésica pretende-se, entre outras coisas, reduzir a ansiedade (sedação), controlar a dor (analgesia), inibir a salivação. A indução da anestesia é, como já se disse, feita por anestésicos intravenosos de curta duração e neurölépticos, embora na criança seja realizada com a inaláção de uma mistura de protóxido de azoto, halotano e oxigénio. Excepto nos casos em que toda a anestesia se faz sob anestesia intravenosa, a manutenção desta realiza-se com os agentes de inalação (geralmente associados a relaxantes musculares, analgésicos opiáceos e sob ventilação controlada). O recobro é executado por supressão do fornecimento do anestésico e se necessário com a ajuda de alguns antagonistas dos adjuvantes usados no processo.

Em resumo, a anestesia geral é uma intervenção farmacológica aguda em que muitos fármacos são usados ao mesmo tempo e daí a necessidade de um conhecimento perfeito das suas características.

\section{ANESTÉSICOS LOCAIS}

Os anestésicos locais são um grupo de agentes quimicamente semelhantes que bloqueiam reversivelmente a geração e a condução de impulsos através da fibra nervosa com que entram em contacto localmente. A sua acção resulta da capacidade de deprimir os impulsos oriundos dos nervos aferentes da pele, superfícies das mucosas e músculos, ao sistema nervoso central. Estes fármacos são amplamente usados em cirurgia, odontologia e oftalmologia para produzir perda da sensação dolorosa, com ou sem perda associada de outras sensações (por ex. temperatura, tacto, etc.).

TABELA 2

Anestésicos locais mais frequentes

\begin{tabular}{|c|c|c|}
\hline Subgrupo & Nome & Estrutura \\
\hline \multirow{4}{*}{ Esteres } & Cocaina & \\
\hline & Procaína & \\
\hline & Benzocaina & \\
\hline & Tetracaína & \\
\hline \multirow{4}{*}{ Amidas } & Lidocaina & \\
\hline & Bupivacaina & \\
\hline & Mepivacaína & \\
\hline & Prilocaina & \\
\hline
\end{tabular}


Para induzir a anestesia local são empregues diversas técnicas, sendo algumas das mais comuns as seguintes: anestesia tópica ou superficial - obtida pela aplicação, na pele e mucosas, de fármacos na forma de especialidades de uso tópico (cremes, pomadas, soluçø̃es, aerossóis, geleias e supositórios); anestesia por infiltração - quando se injecta o anestésico no tecido subcutâneo (por ex. para a extracção de um dente); anestesia raquidiana ou subdural - por administração intra-raquídea do fármaco no líquido cefalorraquidiano espinhal; e outras como a anestesia local intravenosa (na veia superficial dum membro garrotado); anestesia epidural (no espaço extradural, isto é, no exterior da dura-máter espinhal; a dura-máter é a membrana que envolve o cérebro e a medula espinhal).

Do ponto de vista químico há uma certa homogeidade, a maioria dos anestésicos locais são ésteres ou amidas de derivados simples do benzeno com a característica comum de possuirem um grupo aminado hidrofilico e um resto lipofílico, portanto uma estrutura bipolar (ver Tabela 2).

A função amina dá-lhes características de bases fracas, existindo nos líquidos orgânicos como uma mistura de formas livre e ionizada em equilíbrio. O grau de ionização é função do $\mathrm{pKa}$ do composto (geralmente entre 8.0 e 9.0 , excepto para a benzocaína) e do $\mathrm{pH}$ do meio. A acidificaçåo do meio (como acontece nos tecidos inflamados) aumenta a concentração relativa da forma protonada o que lhes diminui a intensidade da acção. Por outro lado, como os anestésicos locais são administrados em forma de sais solúveis (normalmente cloridratos) - forma inactiva - um $\mathrm{pH}$ baixo dificulta a libertação da sua forma activa. Estes fármacos são prontamente absorvidos pelos tecidos envolventes do local de administração, o que diminui a duração do seu efeito. A lipossolubilidade e velocidade de hidrolise condicionam, igualmente, a duraçăo do seu efeito. A administração conjunta de um vasoconstritor é corrente e tem por finalidade limitar o fluxo sanguíneo na zona, a fim de prolongar a acção anestésica.

A biotransformação dos anestésicos locais depende da estrutura química. A metabolização dos ésteres é feita pelas colinesterases plasmáticas (hidrólise) e é muito rápida - a meia-vida é de 30 segundos a alguns minutos. A amidas são hidrolisadas no fígado, pelos enzimas microssomáticos, e a sua meia-vida é de várias horas.

As acçōes farmacológicas destes fármacos são diversas embora, a primeira seja a de anestésico local, acção, no entanto, inespecífica. Estes compostos actuam sobre as estruturas nervosas periféricas, mas podem também actuar noutras estruturas excitáveis do organismo (por ex. o SNC, o aparelho cardiovascular).

Para o mecanismo de acção admite-se que os anestésicos locais, após fixação na face exterior da membrana do axbnio pelo seu polo lipofilico, atravessam a membrana lipídica na forma não ionizada (mais lipossolúvel), provocando constrição nos canais de sódio e interagem com receptores específicos, provalvemente na forma ionizada, na face axoplasmática (interior) da membrana bloqueando os canais de sódio. O bloqueio dos canais de sódio e a diminuição do afluxo de iōes impedem a despolarização da membrana bloqueando a transmissão (e geração) dos impulsos nervosos. Convém referir aqui, que a transmissão dos impulsos nervosos advém da despolarização da membrana da célula nervosa, que resulta dum aumento transitório e intenso da sua permeabilidade aos iðes $\mathrm{Na}^{+}$e $\mathrm{K}^{+}$. Do que foi exposto, infere-se que tanto a forma ionizada como a não ionizada do anestésico desempenham um papel importante na chegada aos receptores e, portanto, no efeito anestésico. Existem outros aspectos, que influenciam a acção destes agentes, como a variação da afinidade para o receptor, que está dependente do estado do canal de sódio (descanso, aberto, inactivado) e como a diferente sensibilidade dos diversos tipos de fibras nervosas, a qual está dependente do diâmetro do grau de mielinização (a mielina é a substância lipídica que envolve, diferentemente, algumas fibras nervosas) e da velocidade físiologica de condução dos impulsos (o período de latência diminui com a diminuição do diâmetro, a diminuição da mielinização e como a maior rapidez da transmissão do impulso nas fibras). Os efeitos tóxicos mais importantes são os que ocorrem no SNC e resultam, em geral, de sobredosagem. Quando esta é ligeira surgem palidez, ansiedade, náuseas, vómitos e sensação de peso na língua. Em caso de concentração plasmática muito elevada (administração intravenosa, normalmente) surgem convulsões, insuficiência circulatória com hipotensão, choque e paragem respiratória. Em doentes com doenças cardiovasculares podem aparecer distúrbios cardíacos. A amida bupivacaina tem sido referida como tendo uma toxicidade cardiovascular mais elevada que os anestésicos de acção rápida e a amida prilocaína é metabolizada a produtos capazes de causar metahemoglobinémia. Os anestésicos locais do tipo éster são metabolizados a produtos que provocam formação de anticorpos em alguns pacientes, causando uma sensibilização alérgica. $\mathrm{O}$ uso dos anestésicos locais não se restringe às pequenas intervençøes cirúrgicas: o tratamento de dores crónicas neoplásicas, de dores pós-operatórias e a analgesia durante o parto (anestesia epidural) são outros dos seus usos.

Refira-se, por último, que os acidentes provocados pelos anestésicos gerais são menos frequentes que os provocados pelos anestésicos locais.

\section{Referências}

- J, Garret e W, Oswald, "Terapêutica Medicamentosa e suas Bases Farmacologicas", vol. I, 2." ed., Porto Editora, Lda., 1986

- B.G. Katsung e A.J. Trevor, "Pharmacology - a reviewn, Large Medical Publications, Los Angeles, 1987

- W.C. Cutting, «Manual de Farmacologia», Montaner y Simon, SA, Barcelona, 1966

- A. Korolkovas e J.H. Burckhalter, "Química Farmacêutican, Ed, Guanabara Dois, SA, Rio de Janeiro, 1982

- W.C. Bownam e M.J. Rand, "Textbook of Pharmacology", 2." ed., Blackwell Scientific Publications, Londres, 1984 